\title{
PROFESIONALITAS GURU MENURUT M. OURAISH SHIHAB DALAM TAFSIR AL-MISHBAH
}

\author{
Amiruddin Siahaan \\ Fakultas Ilmu Tarbiyah dan Keguruan UIN Sumatera Utara \\ Jl. Willem Iskandar Pasar V Medan Estate, Medan, Sumatera Utara, 20371 \\ e-mail: amiruddin.siahaan@gmail.com
}

\begin{abstract}
Abstrak: Penelitian ini bertujuan untuk mengungkap ayat-ayat al-Qur'an yang berkaitan dengan profesionalitas guru. Ayat-ayat tersebut kemudian ditafsirkan menurut Tafsir al-Mishbah karya M. Quraish Shihab. Penelitian ini merupakan penelitian kepustakaan (library research), dan termasuk dalam kategori penelitian kualitatif. Adapun metode yang digunakan adalah metode tematik (maudhû́i), yakni menghimpun ayatayat al-Qur'an yang berbicara tentang profesionalitas guru. Selanjutnya, untuk mengungkap makna-makna serta simbol-simbol dalam ayat-ayatal-Qur'an tentang rumusan profesionalitas guru, penulis menggunakan pendekatan linguistik, semiotik, hermeneutik dan psikologi. Hasil penelitian menunjukkan bahwa pembentukan profesionalitas guru dalam konsep Tafsir al-Mishbah dapat dilakukan melalui upaya membangun kompetensi guru yang profesional berbasis nilai-nilai Islami, menciptakan lingkungan belajar yang kondusif dan bercirikan nilai-nilai Islami, menciptakan suasana pembelajaran yang efektif berciri khas Islam, dan mendukung tercapainya tujuan pendidikan nasional dengan pengembangan berbagai kompetensi profesionalitas guru.
\end{abstract}

\begin{abstract}
Teacher's Professionalism in M. Quraish Shihab's Tafsir alMishbah. This study aims to reveal Quranic verses related to teacher's professionalism. The verses are interpreted through Tafsir al-Mishbah the works of M. Quraish Shihab. This research is a library research and categorise as qualitative research. The method use is thematic method (maudhû́i) which collecting the verses of al-Qur'an that tell about the teacher's professionalism. Then to uncover the meanings and symbols use in the verses of al-Qur'an which formulate the teachers' profesionalisms, the authors use linguistics, semiotics, hermeneutics and psychology approaches. The result of the research showed that the formation of the teachers' professionalism in Tafsir alMishbah concept can be done through, building teachers' profesionalism competencies based on Islamic values, creating conducive learning and Islamic values characteristics, creating effective learning with Islamic characteristics, and supporting the purposes of national education with development of teachers' profesionalism competencies.
\end{abstract}

Kata Kunci: al-Qur'an, M. Quraish Shihab, Tafsir al-Mishbah, profesionalitas, guru 


\section{Pendahuluan}

Kualitas guru di Indonesia masih tergolong relatif rendah. Hal ini antara lain disebabkan oleh tidak terpenuhinya kualifikasi pendidikan minimal terutama bila mengacu pada amanat Undang-undang (UU) Republik Indonesia (RI) Nomor 14 tahun 2005 tentang Guru dan Dosen (UUGD), dan Peraturan Pemerintah (PP) RI Nomor 19 tahun 2005 tentang Standar Nasional Pendidikan (SNP). Dari sisi kualifikasi pendidikan, hingga saat ini, dari 2,92 juta guru, baru sekitar 51 persen yang berpendidikan S-1 atau lebih, sedangkan sisanya belum berpendidikan S-1. Begitu pun dari persyaratan sertifikasi, hanya 2,06 juta guru atau sekitar 70,5 persen guru yang memenuhi syarat sertifikasi. Adapun 86.167 guru lainnya belum memenuhi syarat sertifikasi, yakni sertifikat yang menunjukkan guru tersebut profesional.

Apabila dilihat kondisi guru di Sumatera Utara hingga kini masih memprihatinkan. Dari 194.405 tenaga pengajar, 50,13\% atau 99.387 orang belum memenuhi kualifikasi pendidikan sarjana (S-1). Dari total 95.018 guru yang sudah bergelar sarjana itu, baru sedikit yang mengajar di tingkat pendidikan dasar, yakni pendidikan anak usia dini (PAUD) 25,5\%, dan sekolah dasar (SD) 30,47\%. Sementara guru berpendidikan sarjana untuk tingkat sekolah menengah pertama (SMP) sudah mencapai 72,40\%, dan SMA sebesar 87,17\%. Persoalan ini tidak akan bisa diselesaikan hingga tahun $2015 .{ }^{1}$ Persoalan lemahnya kompetensi fungsi personil pendidikan selama ini memang berada dalam lingkup operasional, struktural, dan kultural. Ketiga dimensi ini kerap menjadi bagian yang setiap saat mengalami kendala, dan memang tidak mudah untuk menyelesaikannya walaupun solusi telah diberikan berbagai pihak. $^{2}$

Sebagai salah satu komponen pendidikan, guru merupakan salah satu bagian terpenting yang terlibat dan bersentuhan secara langsung dengan proses pendidikan itu sendiri. Pada hakikatnya, penyelenggaraan dan keberhasilan proses pendidikan pada semua jenis dan jenjang pendidikan ditentukan oleh profesionalisme dan kinerja atau unjuk kerja yang ditampilkan dari seorang guru, dan kemudian ditunjang oleh unsur-unsur lainnya. Dengan demikian, dalam upaya mewujudkan tujuan pendidikan dan usaha meningkatkan mutu pendidikan, guru merupakan komponen pertama yang harus dibina terlebih dahulu dan dikembangkan secara terus-menerus. ${ }^{3}$

Kebutuhan akan adanya guru yang profesional di Indonesia merupakan suatu keniscayaan. Karena maju mundurnya pendidikan Indonesia berada di tangan-tangan dingin para guruguru, dan guru pula sebagai garda terdepan dalam pembentukan karakter siswa. Guru

1"99.387 Guru Belum Sarjana, Pemerintah Diminta Biayai Pendidikan Guru," dalam http:// koran-sindo.com, 12 November 2013, diakses 15 Mei 2014.

${ }^{2}$ Amiruddin Siahaan dan Tohar Bayoangin, Manajemen Pengembangan Profesi (Bandung: Citapustaka Media, 2014), h. 40.

${ }^{3}$ Rachman Halim Yustiyawan dan Desi Nurhikmahyanti, "Pengaruh Motivasi dan Kompetensi Profesional Guru yang Bersertifikasi terhadap Kinerja Guru di SMP Negeri 1 Surabaya," dalam Jurnal Inspirasi Manajemen Pendidikan, Vol. 3. No. 3, 2014, h. 115. 
idaman merupakan produk dari keseimbangan antara penguasaan aspek keguruan dan disiplin ilmu. ${ }^{4}$ Keduanya tidak perlu dipertentangkan melainkan bagaimana guru tertempa kepribadiannya dan terasah aspek penguasaan materi. Kepribadian guru yang utuh dan berkualitas sangatlah penting, karena dari sinilah muncul tanggung jawab profesional sekaligus menjadi menjadi inti kekuatan profesional dan kesiapan untuk selalu mengembangkan diri. Tugas guru adalah merangsang potensi peserta didik dan mengajarnya supaya belajar. Guru tidak membuat peserta didik menjadi pintar. Guru hanya memberikan peluang agar potensi itu ditemukan dan dikembangkan. Kejelian itulah yang merupakan ciri kepribadian profesional. ${ }^{5}$

Undang-Undang No. 14 Tahun 2005 tentang Guru dan Dosen menyebutkan bahwa kompetensi adalah seperangkat pengetahuan, keterampilan, dan perilaku yang harus dimiliki, dihayati, dikuasai, dan diaktualisasikan oleh guru dalam melaksanakan tugas keprofesionalan. Undang-Undang Guru dan Dosen Pasal 10 ayat (1) menyebutkan kompetensi guru sebagaimana dimaksud dalam Pasal 8 meliputi kompetensi pedagogik, kompetensi kepribadian, kompetensi sosial, dan kompetensi profesional yang diperoleh melalui pendidikan profesi. Dapat dipahami bahwa jika guru memiliki empat kompetensi sebagaimana yang disebutkan dalam undangundang di atas, guru tersebut tergolong guru yang profesional. Guru profesional inilah yang diyakini dapat merubah wajah pendidikan Indonesia menjadi lebih baik pada masa yang akan datang.

Penelitian ini mencoba untuk menggali lebih dalam ayat-ayat al-Qur'an yang berbicara tentang profesionalitas guru yang ditafsirkan lewat pemikiran M. Qurais Shihab dalam Tafsir al-Mishbah. Penelitian ini bertujuan untuk mengetahui konsep Tafsir al-Mishbah tentang profesionalitas guru; mengetahui mekanisme pembentukan profesionalitas guru dalam Tafsir al-Mishbah; dan mengetahui implementasi pembentukan profesionalitas guru di Indonesia.

\section{Metode Penelitian}

Paradigma yang digunakan dalam penelitian ini adalah paradigma kualitatif, karenanya metode pengumpulan data dilakukan dengan penelitian kepustakaan (library research). Adapun metode yang digunakan adalah metode tematik (maudu'iy), yakni menghimpun ayat-ayat al-Qur'an yang berbicara tentang profesionalitas guru. Selanjutnya, untuk mengungkap makna-makna serta simbol-simbol dalam ayat-ayat al-Qur'an tentang rumusan profesionalisme guru, akan digunakan pendekatan linguistik, semiotik, hermeneutik dan psikologi. Metode ini digunakan dengan jalan membaca, menelaah buku-buku dan artikel yang berkaitan dengan tema penelitian ini.

Teknik pengumpulan data yang digunakan dalam penelitian ini adalah pengumpulan

${ }^{4}$ Syafruddin Nurdin dan M. Basyiruddin Usman, Guru Profesional dan Implementasi Kurikulum (Jakarta: Ciputat Press, 2003), h. 24.

IIbid., h. 24. 
data literer yaitu dengan mengumpulkan bahan-bahan pustaka yang berkesinambungan (koheren) dengan objek pembahasan yang diteliti. Data yang ada dalam kepustakaan tersebut dikumpulkan dan diolah dengan cara editing, organizing, dan penemuan hasil penelitian.

Analisa data yang dilakukan dalam penelitian ini pada dasarnya merupakan proses pengorganisasian dan mengurutkan data ke dalam kategori dan satuan uraian dasar sehingga dapat ditemukan pola, dan tema yang dapat dirumuskan sebagai hipotesa kerja. Berdasarkan data yang diperoleh untuk menyusun dan menganalisa data-data yang terkumpul dipakai metode deskriptif-analitik. Metode deskriptif-analitik ini akan digunakan untuk melakukan pelacakan dan analisa terhadap pemikiran, dan kerangka metodologis pemikiran M. Quraish Shihab. Selain itu, metode ini akan digunakan ketika menggambarkan dan menganalisa pemikiran M. Quraish Shihab saat ia melakukan penafsiran terhadap ayat-ayat profesionalitas guru.

\section{Hasil dan Pembahasan}

\section{Konsep Tafsir al-Mishbah tentang Profesionalitas Guru}

Al-Qur'an banyak mengungkapkan ayat-ayat yang berkenaan dengan empat kompetensi profesionalitas guru, maka ayat-ayat tersebut akan ditafsirkan melalui Tafsir al-Mishbah karya M. Quraish Shihab. Tafsir al-Mishbah memiliki cara pandang tentang empat kompetensi profesionalitas guru tersebut lewat kajian beberapa ayat-ayat al-Qur'an.

\section{Konsep Tafsir al-Mishbah tentang Kompetensi Pedagogik}

Kemampuan dalam pengelolaan pembelajaran peserta didik yang sekurang-kurangnya meliputi. Pertama, pemahaman landasan kependidikan. Ayat-ayat al-Qur'an yang mengkaji tentang pemahaman wawasan atau landasan kependidikan di antaranya Q.S. al-Baqarah/ 2: 247, Q.S. al-Ankabût/29: 43, Q.S. al-Zumâr/39: 9, Q.S. al-Kahfi/18: 65, dan Q.S. alNaml/27: 38-40. Dari ayat-ayat ini dipahami bahwa wewenang memerintah bukanlah atas dasar keturunan, tetapi atas dasar pengetahuan dan kesehatan jasmani, bahkan di sini diisyaratkan bahwa kekuasaan yang direstui-Nya adalah yang bersumber dari-Nya. Di sisi lain, ayat ini mengisyaratkan bahwa bila seseorang ingin dipilih, janganlah terpedaya oleh keturunan, kedudukan sosial, atau popularitas, tetapi hendaknya atas dasar kepemilikan sifat-sifat dan kualifikasi yang dapat menunjang tugas yang akan dibebankan kepada yang dipilih itu. ${ }^{6}$ Dari berbagai penafsiran ayat-ayat di atas dengan pendekatan Tafsir al-Mishbah, dapat disimpulkan bahwa kesuksesan suatu bidang keahlian, keterampilan dan keilmuan dilatar belakangi oleh kemampuan keilmuan yang mumpuni.

${ }^{6}$ M. Quraish Shihab, Tafsir al-Misḩbah: Pesan, Kesan dan Keserasian al-Qur'ân, Vol. I (Jakarta: Lentera Hati, 2011), h. 644. 
Kedua, pemahaman terhadap peserta didik. Ayat-ayat al-Qur'an yang mengkaji tentang pemahaman terhadap peserta didik di antaranya: Q.S. al-Isrâ'/17: 84, dan Q.S. al-Najm/53: 8-10. Dalam Q.S. al-Isrâ'/17: 84 terdapat kata شـــــ pada mulanya digunakan untuk cabang pada suatu jalan. Ibn 'Asyur memahami kata ini dalam arti jalan atau kebiasaan yang dilakukan oleh seseorang. Sayyid Quthb memahaminya dalam arti cara dan kecenderungan. Ayat ini menunjukkan bahwa setiap manusia memiliki kecenderungan, potensi, dan pembawaan yang mendorong aktivitasnya. Sementara sebagian pakar berpendapat bahwa ada empat tipe manusia. Ada yang memiliki kecenderungan beribadah, ada lagi yang senang meneliti dan tekun belajar, dan pekerja keras dan yang keempat adalah seniman. Semua berbeda penekanan aktivitasnya. ${ }^{7}$

Ayat-ayat di atas menggambarkan bahwasanya kedekatan guru dan murid harus bisa menjalin komunikasi yang efektif. Memberikan tugas secara independen, menghindari kekerasan/kekangan dan menciptakan kegiatan kegiatan yang dapat merangsang otak, memberi kesempatan kepada peserta didik untuk berpikir reflektif terhadap setiap masalah yang dihadapi, menghargai perbedaan individu peserta didik, dengan melonggarkan aturan dan norma kelas, tidak memaksakan kehendak kepada peserta didik, menunjukkan perilakuperilaku baru dalam pembelajaran, mengembangkan tugas-tugas yang dapat merangsang tumbuhnya kreativitas, mengembangkan rasa percaya diri peserta didik dengan membantu mereka mengembangkan kesadaran dirinya secara positif tanpa menggurui dan mendikte mereka, mengembangkan kegiatan-kegiatan yang menarik.

Ketiga, pengembangan kurikulum/silabus. Ayat-ayat al-Qur'an yang mengkaji tentang pemahaman terhadap peserta didik diantaranya Q.S. al-Hasyr/59: 18. Dalam ayat ini terdapat kata taqaddum/dikedepankan, digunakan dalam arti amal-amal yang dilakukan untuk meraih manfaat pada masa datang. Perintah memperhatikan apa yang telah diperbuat untuk hari esok dipahami oleh Thabathaba'i sebagai perintah untuk melakukan evaluasi terhadap amal-amal yang dilakukan. Ini seperti seorang tukang yang telah menyelesaikan pekerjaannya. Ia dituntut untuk memperhatikannya kembali agar menyempurnakannya bila telah baik, atau memperbaikinya bila masih ada kekurangannya, sehingga jika tiba saatnya diperiksa, tidak ada lagi kekurangan dan barang tersebut tampil sempurna. ${ }^{8}$

Dari paparan di atas dapat dipahami bahwa untuk menghadapi masa depan yang lebih baik, perlu diadakan peningkatan dan pengembangan. Kalau hal ini dihubungkan dengan dunia pendidikan, maka untuk meningkatkan hasil belajar siswa dan meningkatkan kemampuan mengajar guru perlu dilakukan pengembangan kurikulum/silabus. Ketika seorang guru mengembangkan kurikulum dan silabus, maka akan menimbulkan manfaat yang sangat besar, karena hal tersebut mengarah kepada sesuatu yang lebih baik.

Keempat, perancangan pembelajaran. Ayat-ayat al-Qur'an yang mengkaji tentang

${ }^{7}$ Shihab, Tafsir al-Mishbbah, Vol. VII, h. 179.

${ }^{8}$ Ibid., Vol. XIII, h. 552-553. 
perancangan pembelajaran di antaranya Q.S. al-Alaq/96: 1-4, dan Q.S. al-Qalam/68: 1-4. Dalam Q.S. al-Alaq/96: 1-4 terdapat kata Iqra'. Iqra' adalah bentuk kata imperatif (fil amr) terambil dari kata kerja qara'a yang pada mulanya berarti "menghimpun". Menurut Quraish Shihab, arti asal kata ini menunjukkan bahwa iqra' yang diterjemahkan dengan "bacalah!" tidak mengharuskan adanya suatu teks tertulis sebagai objek baca. Ia tidak pula harus diucapkan sehingga terdengar oleh orang lain. Karena itu, dalam kamus, dapat ditemukan arti yang beraneka ragam bagi kata ini. Antara lain, menyampaikan, menelaah, mendalami, meneliti, mengetahui ciri-ciri sesuatu, yang kesemuanya bermuara pada arti "menghimpun". 9

Menurut al-Marâghi, pengulangan iqra' pada ayat tersebut didasarkan pada alasan bahwa membaca itu tidak akan membekas dalam jiwa kecuali dengan pengulangan serta pembiasaan. Perintah Tuhan untuk mengulang-ulang kegiatan membaca, juga berarti mengulangi objek bacaan. Dengan cara seperti itu, bacaan akan menjadi orang yang membacanya. ${ }^{10}$ Dengan demikian, ayat ketiga ini erat hubungannya dengan metode pendidikan dan urgensi pengembangannya.

Di sisi lain, kata qalam dalam ayat di atas dapat menampung seluruh pengertian yang berkaitan dengan segala sesuatu sebagai alat penyimpan, dan perekam. Dalam kaitan ini, qalam dapat mencakup alat pemotret, berupa kamera, alat perekam, berupa tape recorder; alat penyimpan data, berupa komputer, mikro film, video compact disc (VCD). ${ }^{11}$

Dari penjelasan-penjelasan di atas, dapat disimpulkan bahwa Tafsir al-Mishbah mengisyaratkan, proses pembelajaran harus dirancang sebaik mungkin. Perancangan pembelajaran tersebut harus memanfaatkan teknologi serta memberdayakan teknologi dalam setiap proses pembelajaran yang akan dilakukan.

Kelima, pelaksanaan pembelajaran yang mendidik dan dialogis. Ayat-ayat al-Qur'an yang mengkaji tentang pelaksanaan pembelajaran yang mendidik dan dialogis di antaranya Q.S. Âli ‘Imrân/3: 79, dan Q.S. al-Nahll/16: 125. Pada Q.S. Âli 'Imrân/3: 79 terdapat kata rabbani diambil dari kata rabba yang memiliki aneka makna, antara lain pendidik dan pelindung. ${ }^{12}$ Ayat ini menjelaskan bahwa seorang rabbani (pendidik) harus terus menerus mengajar, karena manusia tidak pernah luput dari kekurangan. Seandainya si A telah tahu, si B dan si C boleh jadi belum tahu atau lupa, atau mereka adalah generasi muda yang selama ini belum mengetahui. Di sisi lain, rabbani (pendidik) bertugas terus menerus membahas dan mempelajari kitab suci karena firman Allah sedemikian luas kandungan

${ }^{9}$ Di dalam al-Qur'an, kata qarâ'a disebutkan sebanyak tiga kali, masing-masing pada surah ke-17, ayat 14 dan surah ke-96, ayat 1 dan 3. M. Quraish Shihab, Tafsir al-Qur'an al-Karîm: Tafsir atas Surat-Surat Pendek Berdasarkan Urutan Turunnya Wahyu (Bandung: Pustaka Hidayah, 1997), h. 77-78.

${ }^{10} \mathrm{~A}$ hmad Mushthafâ al-Marâgî, Tafsîr al-Marâgî (Beirut: Dâr al-Fikr, t.t.), h. 199.

${ }^{11}$ Abuddin Nata, Tafsir Ayat-Ayat Pendidikan: Tafsîr al-Âyât al-Tarbawiy (Jakarta: RajaGrafindo Persada, 2002), h. 49.

${ }^{12}$ Shihab, Tafsir al-Mishbah, Vol. II, h. 160. 
maknanya, sehingga semakin digali semakin banyak yang dapat diraih, walaupun yang dibaca dalam teks yang sama. ${ }^{13}$

Selanjutnya pada Q.S. al-Nahl/16: 125 dijelaskan bagaimana metode dalam mengajar/ berdakwah. Quraish Shihab menjelaskan bahwa sebagian ulama memahami bahwa ayat ini menjelaskan tentang tiga metode dakwah yang harus disesuaikan dengan sasaran dakwah. Terhadap cendikiawan yang memiliki intelektual tinggi diperintahkan menyampaikan dakwah dengan hikmah, yakni berdialog dengan kata-kata yang bijak sesuai dengan tingkat kepandaian mereka. Terhadap kaum awam diperintahkan untuk menyampaikan 'izzah, yakni memberikan nasihat dan perumpamaan yang menyentuh jiwa sesuai dengan taraf pengetahuan mereka yang sederhana. Terhadap Ahl al-Kitab dan penganut agama-agama lain yang diperintahkan menggunakan jidal ahsan/perdebatan dengan cara yang terbaik, yaitu dengan logika dan retorika yang halus, lepas dari kekerasan dan umpatan. ${ }^{14}$

Dari berbagai paparan di atas maka dapat disimpulkan bahwa pendidik tidak boleh mudah berputus asa dalam mendidik muridnya, karena tidak semua peserta didik mudah untuk didik, dengan kesabaran dan keuletan dari pendidik, maka kesuksesan pun akan mudah diraih oleh peserta didik. Pelaksanaan pembelajaran yang mendidik dan dialogis dapat dilaksanakan oleh para pendidik melalui pemanfatan berbagai metode mengajar yang komunikatif.

Keenam, pemanfaatan teknologi pembelajaran. Ayat-ayat al-Qur'an yang mengkaji tentang pemanfaatan teknologi pembelajaran di antaranya Q.S. al-Alaq/96: 4. Pada ayat ini terdapat isyarat pada kata al-qalam yang berarti memotong ujung sesuatu. M. Quraish Shihab menjelaskan bahwa kata "al-qalam" ada yang memahaminya dalam arti sempit, yakni pena tertentu. Ada juga yang memahaminya secara umum yaitu alat tulis apa pun termasuk komputer canggih sekalipun. Lalu yang memahaminya dalam arti sempit, ada memahami sebagai pena yang digunakan malaikat untuk menulis takdir baik dan buruk serta segala kejadian dan makhluk yang tercatat di Lauh Mahfudh. Tafsir al-Mishbah ini berpendapat bahwa memahami qalam secara umum lebih tepat, dan ini sejalan dengan perintah membaca yang merupakan wahyu pertama. ${ }^{15}$

Dari penjelasan-penjelasan di atas, dapat disimpulkan bahwa secara kontekstual, ayat yang ditafsirkan ini mengisyaratkan pentingnya pengembangan teknologi pendidikan dan proses pembelajaran harus berbasis teknologi. Kata qalam mengisyaratkan sebuah alat yang digunakan untuk proses pembelajaran.

Ketujuh, evaluasi proses dan hasil belajar. Ayat-ayat al-Qur'an yang mengkaji tentang evaluasi proses dan hasil belajar di antaranya Q.S. al-Ankabût/29: 2-3 dan Q.S. al-Hasyr/ 59: 18. Quraish Shihab menjelaskan bahwa perintah memperhatikan apa yang telah diperbuat untuk hari esok pada ayat ini dipahami oleh Thabâthabầî sebagai perintah untuk melakukan

\footnotetext{
${ }^{13}$ Ibid., h. 160.

${ }^{14}$ Ibid., h. 774.

${ }^{15}$ Ibid., h. 242.
} 
evaluasi terhadap amal-amal yang telah dilakukan. Ini seperti seorang tukang yang telah menyelesaikan pekerjaannya. Ia dituntutuntukmemperhatikannyakembaliagarmenyempurnakannya bila telah baik, atau memperbaikinya bila masih ada kekurangannya, sehingga jika tiba saatnya diperiksa, tidak ada lagi kekurangan dan barang tersebut tampil sempurna. ${ }^{16}$

Evaluasi merupakan suatu hal yang sangat penting untuk mengetahui sampai sejauh mana kemajuan yang telah peserta didik capai, agar sebagai seorang pendidik bisa mengetahui apa yang harus dilakukan dan metode apa yang seharusnya di berikan kepada anak didik tersebut.

Kedelapan, pengembangan potensi peserta didik. Ayat-ayat al-Qur'an yang mengkaji tentang pengembangan peserta didik untuk mengaktualisasikan berbagai potensi yang dimilikinya, di antaranya: Q.S. al-Mu'minûn/23: 12-14, Q.S. al-Kahfi/18: 66-68, dan Q.S. al-Kahfi/18: 79-82. Ayat ini menceritakan asal kejadian manusia yang dimulai sulalah min thin yang berarti saripati dari tanah. Kata sulalah terambil dari kata salla yang antara lain berarti mengambil, mencabut. Patron kata ini mengandung makna sedikit sehingga kata sulalah berarti mengambil sedikit dari tanah dan yang diambil itu adalah saripatinya. ${ }^{17}$ Kemudian proses itu dilanjutkan sampai janin manusia tadi lahir ke muka bumi.

Sebelum akhir ayat ini ditemui kata ansya'a yang mengandung makna mewujudkan sesuatu serta memelihara dan mendidiknya. Penggunaan kata tersebut dalam menjelaskan proses terakhir dari kejadian manusia mengisyaratkan bahwa proses terakhir itu benarbenar berbeda sepenuhnya dengan sifat, ciri, dan keadaannya dengan apa yang ditemukan pada proses sebelumnya. Hal ini tercapai karena Allah mewujudkannya sambil memelihara dan mendidiknya. ${ }^{18}$

Dengan demikian, dapat dirumuskan bahwa tujuan pendidikan dalam kajian Tafsir al-Mishbah adalah upaya membina jasmani dan ruhani manusia dengan segenap potensi yang ada pada keduanya secara berimbang, sehingga dapat dilahirkan manusia yang seutuhnya. Dari sini pula dapat dirumuskan materi pendidikan dengan ungkapan bahwa materi pendidikan harus berisi bahan-bahan pelajaran yang dapat menumbuhkan, mengarahkan, membina, dan mengembangkan potensi-potensi jasmaniah dan ruhaniah secara seimbang.

\section{Konsep Tafsir al-Mishbah tentang Kompetensi Kepribadian}

Pertama, berakhlak mulia. Ayat-ayat al-Qur'an yang mengkaji tentang seorang guru seyogyanya memiliki akhlak mulia di antaranya: Q.S. Âli 'Imrân/3: 102, Q.S. al-Ahhzâb/ 33: 70, Q.S. al-Mâ'idah/5: 8, dan Q.S. al-Baqarah/2: 272. Quraish Shihab menjelaskan bahwa perkataan yang tepat-baik diucapkan dengan lidah dan didengar orang banyak

\footnotetext{
${ }^{16}$ Ibid., h. 552-553.

${ }^{17}$ Ibid., h. 337.

${ }^{18}$ Ibid., h. 339.
} 
maupun yang tertulis sehingga terucapkan oleh diri sendiri dan orang lain ketika membacanya akan tersebar luas informasi dan memberi pengaruh yang tidak kecil bagi jiwa dan pikiran manusia. Kalau ucapan itu baik, maka baik pula pengaruhnya, dan apabila buruk maka buruk pula pengaruhnya, dan karena itu ayat di atas menjadikan dampak dari perkataan yang tepat adalah perbaikan amal-amal. ${ }^{19}$

Dari berbagai kajian ayat di atas dapat disimpulkan bahwa akhlak mulia yang harus dimiliki seorang guru yang professional, seperti bertakwa kepada Allah SWT., adil, ikhlas, santun, lemah lembut dan rendah hati. Guru harus mampu menjadi uswah h hasanah bagi para peserta didiknya. Akhlak yang mulia diperlihatkan mulai dari perkataan yang baik. Kemudian akhlak yang mulia itu diwujudkan melalui tindakan dan perilaku yang ditunjukkan oleh seorang guru.

Kedua, arif dan bijaksana. Ayat-ayat al-Qur'an yang mengkaji tentang seorang guru seyogyanya memiliki sikap arif dan bijaksana, di antaranya Q.S. Âli 'Imrân/3: 159. Dalam ayat ini dijelaskan bahwa ada tiga sifat penting yang harus dimiliki manusia, yang pertama, berlaku lemah lembut, tidak kasar dan tidak berhati keras. Kedua, memberi maaf dan membuka lembaran baru. Ketiga, melaksanakan segala sesuatu dengan proses musyawarah, dan apabila musyawarah telah disepakati maka bertawakkallah kepada Allah SWT.

Pribadi yang arif bijaksana seperti ini sangat perlu dimiliki seorang guru yang menginginkan anak didiknya memiliki perilaku-perilaku yang baik menurut syariat. Ketiga sifat di atas tentunya menunjukkan sikap seorang yang arif dan bijaksana. Dalam konteks pendidikan guru juga harus memiliki ketiga sifat di atas, berlaku lemah lembut, tidak kasar dan tidak berhati keras, memberi maaf dan membuka lembaran baru, kemudian melaksanakan segala sesuatu dengan proses musyawarah.

Ketiga, berkepribadian mantap. Ayat-ayat al-Qur'an yang mengkaji tentang seorang guru seyogyanya memiliki keperibadian mantap dapat dilihat pada Q.S. Âli 'Imrân/3: 31. Ayat ini berbicara tentang konsep cinta hamba kepada Tuhannya. Cinta manusia kepada Allah adalah suatu kualitas yang mengejewantahkan pada diri seseorang yang beriman sehingga menghasilkan ketaatan kepada-Nya, penghormatan dan pengaguman, dan dengan demikian dia mementingkan Tuhannya dari selain-Nya. Dia menjadi tidak sabar dan resah untuk tidak memandang dan memenuhi kehendak-Nya, dia tidak bisa tenang bersama yang lain kecuali bersama-Nya, dia tidak menyebut yang lain kecuali mengingat-Nya pula, dan kenikmatan yang dikecupnya adalah ketika menyebut-nyebut (berzikir) sambil memandang keindahan dan kebesaran-Nya. ${ }^{20}$

Dengan demikian, seorang guru yang memiliki kepribadian mantap dalam konteks Tafsir al-Mishbah adalah seorang guru yang melaksanakan segala aktivitas keprofesiannya

\footnotetext{
${ }^{19}$ Ibid., h. 547-548.

${ }^{20}$ Ibid., h. 80.
} 
sebagai wujud kecintaannya kepada sang khalik. Dengan demikian akan lahir sebuah karya dan kinerja yang luar biasa sebagai persembahan kepada sang yang dicinta yaitu Allah SWT.

Keempat, berwibawa. Ayat-ayat al-Qur'an yang mengkaji tentang seorang guru seyogyanya memiliki sikap berwibawa, di antaranya Q.S. al-Anbiyâ'/21: 81. Ayat ini berbicara tentang keistimewaan yang diberikan Allah kepada Nabi Sulaiman as. berupa pengendalian terhadap angin. ${ }^{21}$ Ayat ini menunjukkan bagaimana kewibawaan Nabi Sulaiman as. untuk mengendalikan sesuatu. Sampai-sampai angin yang bertiup saja pun dapat dikendalikannya atas izin Allah SWT. Kondisi ini tentunya menjadikan Nabi Sulaiman as. menjadi sosok yang disegani oleh umatnya ataupun para kolega dan musuh-musuhnya.

Dengan demikian, jika konsep Tafsir al-Mishbah yang mengkaji ayat ini dihubungkan dengan pendidikan Islam, maka dapat disimpulkan bahwa seorang guru harus mempunyai kewibaan yang baik, yang dapat mengendalikan peserta didiknya kearah yang baik..

Kelima, berkepribadian stabil. Ayat-ayat al-Qur'an yang mengkaji tentang seorang guru seyogianya memiliki kepribadian stabil, di antaranya Q.S. al-Isrâ'/17: 36. Quraish Shihab mengungkapkan bahwa Sayyid Quthb pernah berkomentar bahwa ayat ini dengan kalimat-kalimatnya yang sedemikian singkat telah menegakkan suatu sistem yang sempurna bagi hati dan akal, mencakup metode ilmiah yang baru saja dikenal umat manusia, bahkan ayat ini menambah sesuatu yang berkaitan dengan hati manusia yaitu pengawasan Allah SWT. Tambahan dan penekanan ini merupakan keistimewaan Islam dibandingkan dengan metode-metode penggunaan nalar yang dikenal selama ini dan yang sangat gersang itu. ${ }^{22}$

Kalau konteks ayat di atas dihubungkan dengan konteks pendidikan, maka seorang pendidik harus memiliki jiwa yang stabil, kepribadian yang stabil serta konsisten dalam mengambil sebuah keputusan dan tindakan dengan tidak mudah terpengaruh oleh pendapat orang lain yang belum tentu kebenarannya. Oleh sebab itu, seorang pendidik harus memiliki pengetahuan yang mumpuni di bidangnya hingga tidak mudah terpengaruh dan terprovokasi dengan pendapat dan argumentasi orang lain.

Keenam, dewasa. Ayat-ayat al-Qur'an yang mengkaji tentang seorang guru seyogianya memiliki sikap dewasa di antaranya: Q.S. al-Nisâ'/4: 58. Ayat ini berbicara tentang amanah dan siapa yang berhak menerima amanah tersebut. Quraish Shihab menyertakan bahwa ketika memerintahkan untuk menetapkan hukum dengan adil, ayat ini memulainya dengan menyatakan: apabila kamu menetapkan hukum di antara manusia. Tetapi sebelumnya ketika memerintahkan menunaikan amanah, redaksi semacam ini tidak ditemukan. Ia mengisyaratkan bahwa manusia telah menerima amanah secara potensial sebelum kelahirannya dan secara aktual sejak ia akil baligh. ${ }^{23}$

${ }^{21}$ Ibid., h. 101-102.

${ }^{22} I b i d .$, h. 87.

${ }^{23}$ Lihat Q.S. al-Ahzâb/33: 72. 
Dengan demikian konsep Tafsir al-Mishbah tentang kompetensi kepribadian guru dalam bentuk kedewasaan berarti seorang pendidik harus memiliki usia yang dewasa, pengetahuan yang mendalam serta kedewasaan berpikir (kematangan berpikir). Dengan kompetensi yang dimiliki ini, maka seorang pendidik akan mampu bertanggung jawab dengan amanah yang diterimanya.

Ketujuh, jujur. Ayat-ayat al-Qur'an yang mengkaji tentang seorang guru seyogianya memiliki sikap jujur di antaranya Q.S. al-Shâf/61: 2-3. Ayat ini merupakan kecaman yang ditujukan kepada mereka yang berjanji akan berjihad, tetapi ternyata enggan melakukannya. Ibn Katsir menuturkan bahwa mayoritas ulama menyatakan bahwa ayat ini turun ketika kaum Muslim mengharapkan diwajibkannyajihad atas mereka, tetapi ketika Allah mewajibkannya mereka tidak melaksanakannya. Dengan demikian, ayat ini serupa dengan firman-Nya dalam Q.S. al-Baqarah/2: 246 yang berbicara tentang orang-orang Yahudi yang satu ketika mengharap diizinkan untuk berperang tetapi "tatkala perang diwajibkan atas mereka, mereka pun berpaling kecuali sedikit di antara mereka. Riwayat lain menyatakan bahwa ayat di atas turun sebagai kecaman terhadap mereka yang mengatakan: "Kami telah membunuh (musuh), menikam, memukul dan telah melakukan ini padahal mereka tidak melakukannya. Dengan demikian ayat diatas mengecam juga orang munafikyang mengucapkan kalimat syahadat dan mengaku Muslim tanpa melaksnakan secara baik dan benar tuntutan agama Islam". ${ }^{24}$

Dapat disimpulkan bahwa ketidak jujuran merupakan sesuatu yang amat dimurkai oleh Allah SWT. Kalau dihubungkan ayat ini dengan dunia pendidikan, maka diharapkan seorang guru mengedepankan kejujuran ketika mengajar di dalam kelas, apa yang diungkapkan kepada peserta didik adalah hal-hal yang telah dilaksnakan oleh pendidik tersebut.

Kedelapan, menjadi teladan peserta didik dan masyarakat. Ayat-ayat al-Qur'an yang mengkaji tentang seorang guru seyogianya menjadi teladan peserta didik dan masyarakat di antaranya Q.S. Âli 'Imrân/3: 104. Quraish Shihab menjelaskan bahwa tidak dapat disangkal bahwa pengetahuan yang dimiliki seseorang bahkan kemampuannya mengamalkan sesuatu akan berkurang, bahkan terlupakan dan hilang, jika tidak ada yang mengingatkannya atau tidak dia ulang-ulang mengerjakannya. Di sisi lain, pengetahuan dan pengalaman saling berkaitan erat, pengetahuan mendorong kepada pengalaman dan meningkatkan kualitas amal, sedangkan pengalaman yang terlihat dalam kenyataan hidup merupakan guru yang mengajar individu dan masyarakat sehingga mereka pun belajar mengamalkannya. ${ }^{25}$ Kalau demikian halnya, tambah Quraish Shihab, manusia dan masyarakat perlu selalu diingatkan dan diberi keteladanan. Inilah inti dakwah Islamiah. ${ }^{26}$

Dalam tinjaun Tafsir al-Mishbah ini, dapat disimpulkan bahwa perlunya ada sekolompok orang yang dapat mengajak kepada kebaikan, menyeru kepada yang makruf dan mencegah

\footnotetext{
${ }^{24}$ Shihab, Tafsir al-Mishbah, Vol. XIV, h. 11.

${ }^{25}$ Ibid., h. 208-209.

${ }^{26}$ Ibid., h. 209.
} 
kepada yang munkar. Orang tersebut adalah seorang pendidik yang beriman yang dapat menjadi tauladan bagi peserta didik dan masyarakat melalui ucapannya (lisan), melalui karya ilmiahnya (tulisan) dan melalui berbagai aktivitas kehidupannya serta melalui akhlaknya, sehingga pengetahuan pendidik tersebut mendorong kepada pengalaman dan meningkatkan kualitas amal peserta didik dan masyarakat, sedangkan pengalaman yang terlihat dalam kenyataan hidup para pendidik merupakan guru yang mengajar individu dan masyarakat sehingga mereka pun belajar mengamalkannya.

Kesembilan, secara objektif mengevaluasi kinerja sendiri. Ayat al-Qur'an yang mengkaji tentang seorang guru seyogianya secara objektif mengevaluasi kinerja sendiri, di antaranya Q.S. al-Hasyr/59: 18-20. Kata taqaddum/dikedepankan digunakan dalam arti amal-amal yang dilakukan untuk meraih manfaat di masa datang. Perintah memperhatikan apa yang telah diperbuat untuk hari esok dipahami oleh Thabâthabâ' sebagai perintah untuk melakukan evaluasi terhadap amal-amal yang dilakukan. Ini seperti seorang tukang yang telah menyelesaikan pekerjaannya. Ia dituntut untuk memperhatikannya kembali agar menyempurnakannya bila telah baik, atau memperbaikinya bila masih ada kekurangannya. ${ }^{27}$

Dengan demikian dalam konsep Tafsir al-Mishbah dapat disimpulkan bahwa seorang pendidik yang baik adalah pendidik yang secara berkelanjutan terus mengevaluasi dirinya atas apa yang ia lakukan, atas apa yang ia katakan, atas apa yang ia tuliskan, atas apa yang ia rencanakan dan atas apa yang telah dipersembahkannya untuk peserta didik, agama dan bangsa.

Kesepuluh, siap mengembangkan diri secara mandiri dan berkelanjutan. Ayat alQur'an yang mengkaji tentang seorang guru seyogianya mau dan siap mengembangkan diri secara mandiri dan berkelanjutan, di antaranya Q.S. Thâhâ/20: 114. Pada akhir ayat ini ada sebuah kalimat "Ya Tuhanku, tambahkanlah kepadaku ilmu pengetahuan, hal ini menunjukkan bahwa ada keinginan manusia untuk bertambah dan berkembang pengetahuannya ke arah yang lebih baik. Keinginan manusia untuk bertambah dan berkembang pengetahuannya ke arah yang lebih baik menunjukkan sikap manusia yang mau dan siap mengembangkan diri secara mandiri dan berkelanjutan.

Konsep Tafsir al-Mishbah tentang seorang pendidik yang mau dan siap mengembangkan diri secara mandiri dan berkelanjutan adalah seoarang pendidik yang berkualitas dan bermutu dan pendidik yang secara berkelanjutan mau mengembangkan dirinya secara berkelanjutan. Apakah pengembangan kualifikasi akademik, kompetensi, kesehatan jasmani dan ruhani serta kemampuan untuk mewujudkan tujuan pendidikan Islam dan nasional.

\section{Konsep Tafsir al-Mishbah tentang Kompetensi Profesional}

Pertama, kemampuan menguasai materi pelajaran. Ayat al-Qur'an yang mengkaji

${ }^{27} I b i d .$, h. 552-553. 
tentang seorang guru seyogyanya memiliki kemampuan menguasai materi pelajaran secara luas dan mendalam sesuai dengan standar isi program pendidikan, mata pelajaran, dan/atau kelompok mata pelajaran yang diampunya, di antaranya Q.S. al-Ankabût/29: 43. Akhir ayat ini berbicara tentang amtsal al-Qur'ân. Quraish Shihab menjelaskan bahwa firman Allah SWT. yang berbicara tentang amtsal al-Qur'ân seperti pada akhir ayat ini yang berbunyi: "Tiada ada yang memahaminya kecuali orang-orang alim mengisyaratkan bahwa perumpamaan-perumpamaan dalam al-Qur'an mempunyai makna-makna yang dalam, bukan terbatas pada pengertian kata-katanya. Masing-masing orang, sesuai kemampuan ilmiahnya, dapat menimba dari matsal itu, pemahaman yang boleh jadi berbeda, bahkan lebih dalam dari orang lain. Ini juga berarti bahwa perumpamaan yang dipaparkan di sini bukan sekadar perumpamaan yang bertujuan sebagai hiasan kata-kata, tetapi ia mengandung makna serta pembuktian yang sangat jelas. ${ }^{28}$

Dapat disimpulkan bahwa konsep Tafsir al-Mishbah tentang kemampuan guru menguasai materi pelajaran secara luas dan mendalam sesuai dengan standar isi program pendidikan, mata pelajaran, dan/atau kelompok mata pelajaran yang diampunya adalah seorang guru yang memiliki kemampuan untuk menjelaskan materi secara mendalam dengan tidak hanya memperhatikan konsep-konsep, namun lebih dari itu guru tersebut harus dapat memberikan contoh yang aktual, sehingga siswa dapat memahami materi tersebut dengan baik. Selanjutnya, seorang guru juga tidak hanya mampu mengungkap konsep dan contoh, seorang guru juga harus juga mampu memaparkan urgensi konsep dan contoh tersebut dalam kehidupan nyata peserta didik.

Kedua, kemampuan menguasai konsep dan metode disiplin keilmuan. Ayat al-Qur'an yang mengkaji tentang seorang guru seyogianya memiliki kemampuan menguasai konsepkonsep dan metode disiplin keilmuan, teknologi atau seni yang relevan yang secara konseptual menaungi atau koheren dengan program satuan pendidikan, mata pelajaran, dan/atau kelompok mata pelajaran yang akan diampu, di antaranya Q.S. al-Nahll/16: 125 dan Q.S. al22: 46.

Menurut Quraish Shihab, sebahagian ulama memahami bahwa ayat ini menjelaskan tentang tiga metode dakwah yang harus disesuaikan dengan sasaran dakwah. Terhadap cendikiawan yang memiliki intelektual tinggi diperintahkan menyampaikan dakwah dengan hikmah, yakni berdialog dengan kata-kata yang bijak sesuai dengan tingkat kepandaian mereka. Terhadap kaum awam diperintahkan untuk menyampaikan ‘izzah, yakni memberikan nasihat dan perumpamaan yang menyentuh jiwa sesuai dengan taraf pengetahuan mereka yang sederhana. Sedangkan terhadap Ahl al-Kitab dan penganut agama-agama lain yang diperintahkan menggunakan jidal ahsan/perdebatan dengan cara yang terbaik, yaitu dengan logika dan retorika yang halus, lepas dari kekerasan dan umpatan. ${ }^{29}$

\footnotetext{
${ }^{28}$ Ibid., h. 88

${ }^{29}$ Ibid., h. 774.
} 
Dengan demikian konsep Tafsir al-Mishbah tentang kemampuan guru menguasai konsep-konsep dan metode disiplin keilmuan, teknologi atau seni yang relevan yang secara konseptual menaungi atau koheran dengan program satuan pendidikan, mata pelajaran, dan/atau kelompok mata pelajaran yang akan diampu yaitu seorang guru harus menguasai berbagai metode dalam setiap melakukan proses pembelajaran. Kemudian, setiap metode pembelajaran yang ditawarkan guru adalah metode pembelajaran yang tidak hanya bisa dilihat oleh mata dan didengar oleh telinga, namun metode yang ditawarkan adalah metode yang dapat menyentuh hati dan jiwa peserta didik, sehingga dengan metode pembelajaran tersebut dapat menggiring peserta pada hasil belajar yang baik dan mencapai tujuan pendidikan.

\section{Konsep Tafsir al-Mishbah tentang Kompetensi Sosial}

Pertama, berkomunikasi lisan, tulisan dan isyarat. Ayat al-Qur'an yang mengkaji tentang seorang guru seyogianya mampu berkomunikasi lisan, tulisan dan/atau isyarat, di antaranya Q.S. al-Ahzâb/33: 70. Quraish Shihab menyatakan bahwa dengan perkataan yang tepat-baik yang terucapkan dengan lidah dan didengar orang banyak maupun yang tertulis sehingga terucapkan oleh diri sendiri dan orang lain ketika membacanya akan tersebar luas informasi dan memberi pengaruh yang tidak kecil bagi jiwa dan pikiran manusia. Kalau ucapan itu baik, baik pula pengaruhnya. Apabila buruk, maka buruk pula pengaruhnya, dan karena itu ayat di atas menjadikan dampak dari perkataan yang tepat adalah perbaikan amal-amal. ${ }^{30}$

Dengan demikian konsep Tafsir al-Mishbah tentang kemampuan guru dalam berkomunikasi lisan, tulisan dan/atau isyarat ialah kemampuan guru dalam menggunakan bahasa, logika berpikir, penggunaan kata-kata yang syarat makna serta cara penyampaian yang tepat oleh pendidik akan berdampak positif kepada perkembangan peserta didik.

Kedua, menggunakan teknologi komunikasi dan informasi secara fungsional. Ayat al-Qur'an yang mengkaji tentang seorang guru seyogianya menggunakan teknologi komunikasi dan informasi secara fungsional, di antaranya Q.S. al-Furqân/25: 48. Ayat ini menunjukkan kekuasaan dan keesaan-Nya serta kewajarannya untuk disembah. Ayat ini menyatakan bahwa di antara bukti kekuasaan dan keesaannya adalah bahwa Dia yang mengirim angin guna menggiring awan sebagai pembawa kabar gembira sebelum kedatangan rahmatNya, yakni sebelum turunnya hujan, dan Kami turunkan dari langit yakni udara, air yang sangat suci, yakni amat bersih dan dapat digunakan untuk menyucikan, agar kami menghidupkan dengannya, yakni dengan air yang Kami turunkan itu, negeri yakni tanah yang gersang yang mati karena ditumbuhi sesuatu. ${ }^{31}$

Dari paparan di atas dapat disimpulkan bahwa konsep Tafsir al-Mishbah tentang kompetensi guru menggunakan teknologi komunikasi dan informasi secara fungsional

\footnotetext{
${ }^{30} I b i d .$, h. 547-548.

${ }^{31}$ Ibid., h. 102.
} 
adalah suatu keniscayaan. Teknologi komunikasi dan informasi digunakan pendidik sebagai media untuk menyampaikan pembelajaran. Proses pembelajaran pun akan berjalan lebih baik jika guru menguasai teknologi komunikasi dan informasi.

Ketiga, bergaul dengan berbagai pihak di lembaga pendidikan. Ayat al-Qur'an yang mengkaji tentang seorang guru seyogianya bergaul secara aktif dengan peserta didik, sesama pendidik, tenaga kependidikan, pimpinan satuan pendidikan, orang tua/wali peserta pendidik, di antaranya Q.S. al-్ujurat/49: 2. Quraish Shihab menjelaskan bahwa larangan mengeraskan suara di hadapan Nabi SAW. itu tidak berarti bahwa orang yang suara normalnya memang lebih keras daripada suara nabi menjadi terlarang untuk bercakapcakap dengan beliau. Sahabat Nabi Tsabit Ibn Qais Ibn Syammas yang suaranya amat lantang tadinya memahaminya demikian sehingga beliau tinggal di rumahnya sambil menduga bahwa amalnya telah dihapus dan dia menjadi penghuni neraka. Tetapi Nabi Muhammad SAW. menyampaikan bahwa bukan makna itu yang dimaksud dan bukan terhadapnya ayat ini turun. Dia penghuni surga, demikian sabda Nabi SAW. (HR. Bukhârî dan Muslim melalui Anas Ibn Malik). Tidak juga berarti larangan mengeraskan suara pada saat-saat yang dibutuhkan, misalnya azan, atau pengumuman tentang sesuatu. ${ }^{32}$

Dengan demikian konsep Tafsir al-Mishbah tentang kompetensi guru dalam bergaul secara aktif dengan peserta didik, sesama pendidik, tenaga kependidikan, pimpinan satuan pendidikan, orang tua/wali peserta didik yaitu dengan menggunakan komunikasi yang baik, memilih perbendaharaan kata yang santun, penggunaan bahasa yang baik serta penggunaan suara yang baik (sesuai dengan kondisi di mana ia berada).

Keempat, bergaul dengan masyarakat secara santun. Ayat al-Qur'an yang mengkaji tentang seorang guru seyogianya bergaul secara santun dengan masyarakat sekitar dengan mengindahkan norma serta sistem nilai yang berlaku, di antaranya Q.S. al-Hujurât/49: 6, Q.S. al-Hujurât/49: 12 dan Q.S. al-Furqân/25: 63. Quraish Shihab menjelaskan bahwa damai pasif adalah batas antara keharmonisan/kedekatan dan perpisahan serta batas antara rahmat dan siksaan. Seorang Muslim, yakni yang menyandang sifat damai, paling tidak, bila dia tidak dapat memberi manfaat kepada selainnya, jangan sampai dia mencelakakannya. Kalau dia tidak memberi, paling tidak tidak mengambil hak orang lain. Kalau tidak dapat menggembirakan pihak lain, paling tidak dia tidak meresahkannya, dan kalau dia tidak dapat memujinya, minimal ia tidak mencelanya. ${ }^{33}$

Dengan demikian konsep Tafsir al-Mishbah tentang kompetensi kepribadian guru dalam bergaul secara santun dengan masyarakat sekitar dengan mengindahkan norma serta sistem nilai yang berlaku yaitu dengan mengedepankan baik sangka, berbicara dengan lemah lembut serta berbicara berdasarkan pengetahuan bukan ketidak tahuan di samping melakukannya berdasarkan pertimbangan logis dan nilai-nilai yang ditetapkan Allah SWT.

\footnotetext{
${ }^{32}$ Ibid., h. 102-103.

${ }^{33}$ Ibid., h. 615.
} 
Kelima, menerapkan prinsip-prinsip persaudaraan dan semangat kebersamaan. Ayat al-Qur'an yang mengkaji tentang seorang guru seyogianya menerapkan prinsip-prinsip persaudaraan sejati dan semangat kebersamaan, di antaranya Q.S. al-Hujurât/49: 11 dan 13. Ayat di atas melarang melakukan al-lamz terhadap diri sendiri, sedang maksudnya adalah orang lain. Redaksi tersebut dipilih untuk mengisyaratkan kesatuan masyarakat dan bagaimana seharusnya seseorang merasakan bahwa penderitaan dan kehinaan yang menimpa orang lain menimpa pula pada dirinya sendiri. Di sisi lain, tentu saja siapa yang mengejek orang lain maka dampak buruk ejekan itu menimpa si pengejek, bahkan tidak mustahil ia memperoleh ejekan yang lebih buruk dari yang diejek itu. ${ }^{34}$

Dengan demikian konsep Tafsir al-Mishbah tentang menerapkan prinsip-prinsip persaudaraan sejati dan semangat kebersamaan yaitu mengedepan semangat kebersamaan di atas perbedaan, mengedepankan saling melengkapi antara satu dengan yang lainnya, dan mengedapankan perbaikan untuk bersama bukan untuk saling mencela.

\section{Mekanisme Pembentukan Profesionalitas Guru dalam Tafsir al-Mishbah}

Mekanisme pembentukan profesionalitas guru dalam Tafsir al-Mishbah dilakukan melalui lima hal tersebut. Pertama, memahami standar tuntutan profesi yang ada. Hal ini dapat dilihat pada Q.S. al-Mujâdilah/58: 11. Di dalam ayat tersebut ada terdapat kalimat alladzina utu al-‘ilm/yang diberi pengetahuan. Alladzîna utu al-'ilm/yang diberi pengetahuan adalah mereka yang beriman dan senantiasa menghiasi diri mereka dengan pengetahuan. Ini berarti ayat di atas membagi kaum beriman kepada dua kelompok besar, yang pertama sekedar beriman dan beramal saleh dan kedua beriman dan beramal saleh serta memiliki pengetahuan. Derajat kelompok kedua ini menjadi lebih tinggi, bukan saja karena nilai ilmu yang disandangnya, tetapi juga amal dan pengajarannya kepada pihak lain, baik secara lisan, tulisan atau dengan keteladanan. ${ }^{35}$

Konsep Tafsir al-Mishbah tentang memahami standar tuntutan profesi yang ada adalah seorang pendidik mau dan siap mengembangkan diri secara mandiri dan berkelanjutan melalui pendidikan sepanjang hayat. Ini artinya seorang pendidik tidak berhenti untuk belajar setelah menyelesaikan kualifikasi pendidikannya, namun terus berbenah diri untuk menambah ilmunya, baik lewat pendidikan formal, informal dan nonformal yang ditandai dengan permohonan kepada Allah untuk menambah ilmu pengetahuan.

Kedua, mencapai kualifikasi dan kompetensi yang dipersyaratkan. Hal ini dapat dilihat pada Q.S. al-Taubah/9: 122. Ayat ini menggaris bawahi terlebih dahulu motivasi bertafaqquh/ memperdalam pengetahuan bagi mereka yang dianjurkan keluar, motivasi utama mereka yang berperang bukanlah tafaqquh. ${ }^{36}$

\footnotetext{
${ }^{34}$ Ibid., h. 606.

${ }^{35}$ Ibid., h. 491.

${ }^{36}$ Ibid., h. 291-292.
} 
Dengan demikian konsep Tafsir al-Mishbah tentang mencapai kualifikasi dan kompetensi yang dipersyaratkan yaitu setiap guru harus senantiasa meningkatkan kualifikasi akademik dan kompetensinya, agar dengan peningkatan kualifikasi akademik dan kompetensi itu seorang guru dapat memenuhi standar kualifikasi dan kompetensi yang dipersyaratkan.

Ketiga, membangun kesejawatan yang baik dan luas termasuk lewat organisasi profesi. Hal ini dapat dilihat pada Q.S. al-Mâ'idah/5: 2. Menurut Quraish Shihab ayat di atas merupakan prinsip dasar dalam menjalin kerjasama dengan siapa pun selama tujuannya adalah kebajikan dan ketakwaan. ${ }^{37}$ Perintah ta âwun untuk menghadirkan kebaikan dan ketakwaan di tengahtengah manusia merupakan sebuah perintah yang memiliki korelasi dengan prinsip ' $\underline{h a b l}$ min Allâh dan habl min al-nâs'; ta'âwun dalam kebaikan yang bersifat umum merupakan sarana untuk menjaga hubungan baik dengan manusia, sedangkan ta'âwun dalam takwa merupakan sarana untuk meraih rida Allah SWT. sehingga tidak sempurna jika ta'âwun itu hanya dalam al-birr, tetapi harus diteruskan dalam konteks takwa juga.

Konsep Tafsir al-Mishbah tentang membangun kesejawatan yang baik dan luas termasuk lewat organisasi profesi merupakan keniscayaan bagi guru untuk melaksanakan kerjasama dengan berbagai pihak. Dengan kerjasama yang berlandaskan atas kebajikan dan ketakwaan maka akan mendatangkan kemaslahatan. Dalam melakukan kerjasama diperlukannya kesatuan hati antara seorang guru dengan lainnya, sehingga dengan kesatuan hati tersebut setiap permasalahan dapat diselesaikan, dengan kesatuan hati juga berbagai informasi dapat disampaikan dengan penuh keikhlasan dan dengan kesatuan hati pula antara satu dengan yang lainnya akan saling memotivasi untuk menjadi lebih baik.

Keempat, mengembangkan etos kerja atau budaya kerja yang mengutamakan pelayanan. Hal ini dapat dilihat pada Q.S. al-Taubah/9: 105. Ayat ini menurut Thabâthabâ'î dalam Quraish Shihab bertujuan untuk mendorong manusia untuk mawas diri dan mengawasi amal-amal mereka dengan jalan mengingatkan mereka bahwa setiap amal yang baik dan yang buruk memiliki hakikat yang tidak dapat disembunyikan dan mempunyai saksisaksi yang mengetahui dan melihat hakikatnya, yaitu Rasul SAW. dan para saksi amalamal dari kelompok kaum Mukmin setelah Allah SWT. Lalu, Allah akan membuka tabir yang menutupi mata mereka yang mengerjakan amal-amal tersebut pada Hari Kiamat sehingga mereka pun akan mengetahui dan melihat hakikat amal mereka. ${ }^{38}$

Yûsuf al-Qardhâwî menyebutkan bahwa setiap pekerjaan bisa menjadi ladang jihad di jalan Allah jika memenuhi lima syarat. Pertama, hendaknya pekerjaan itu ada dalam koridor syariat Islam. Kedua, harus disertai dengan niat yang baik. Niat seorang Muslim dalam bekerja adalah menjaga kehormatan dirinya, mencukupi kebutuhan keluarga, memberi manfaat bagi umat, dan memakmurkan bumi sebagaimana yang diperintahkan Allah. Ketiga, bekerja dengan tekun dan sebaik-baiknya. Keempat, konsisten dalam berpegang

\footnotetext{
${ }^{37}$ Ibid., h. 17.

${ }^{38}$ Ibid., h. 238-239.
} 
pada ketentuan-ketentuan hukum Allah. Tidak berbuat zalim dan khianat. Kelima, pekerjaan itu tidak boleh melalaikannya dari mengingat Allah. ${ }^{39}$

Konsep Tafsir al-Mishbah tentang mengembangkan etos kerja atau budaya kerja yang mengutamakan pelayanan adalah bekerja merupakan sebuah ibadah, dan apa yang dilakukan seorang manusia dalam bekerja, maka semuanya diawasi oleh Allah dan dilihat oleh orang banyak. Artinya, baik dan buruk pekerjaan yang dilakukan akan bernilai di mata Allah dan akan menjadi penilaian bagi orang lain.

Kelima, mengembangkan kreativitas dalam pemanfaatan teknologi komunikasi dan informasi mutakhir. Hal ini dapat dilihat pada Q.S. al-Furqân/25: 48. Ayat ini menunjukkan kekuasaan dan keesaan-Nya serta kewajarannya untuk disembah. Ayat ini menyatakan bahwa di antara bukti kekuasaan dan keesaannya adalah bahwa Dia yang mengirim angin guna menggiring awan sebagai pembawa kabar gembira sebelum kedatangan rahmat-Nya, yakni sebelum turunnya hujan, dan kami turunkan dari langit yakni udara, air yang sangat suci, yakni amat bersih dan dapat digunakan untuk menyucikan, agar kami menghidupkan dengannya, yakni dengan air yang kami turunkan itu, negeri yakni tanah yang gersang yang mati karena ditumbuhi sesuatu. ${ }^{40}$

Konsep Tafsir al-Mishbah tentang mengadopsi inovasi atau mengembangkan kreativitas dalam pemanfaatan teknologi komunikasi dan informasi mutakhir bagi guru adalah suatu keniscayaan. Teknologi komunikasi dan informasi digunakan pendidik sebagai media untuk menyampaikan pembelajaran. Proses pembelajaran pun akan berjalan lebih baik jika guru menguasai teknologi komunikasi dan informasi. Itulah mengapa pemilihan dalam menetapkan media merupakan hal yang sangat penting dan harus dipertimbangkan secara seksama oleh guru.

\section{Kesimpulan dan Saran}

Berdasarkan analisa di atas, dapat ditarik kesimpulan sebagai berikut. Pertama, konsep Tafsir al-Mishbah tentang profesionalitas guru adalah sebagai berikut (1) konsep Tafsir al-Mishbah tentang kompetensi pedagogik, terdiri atas kemampuan keilmuan yang mumpuni, mampu menerapkan teori belajar dan pembelajaran serta dapat menentukan strategi pembelajaran berdasarkan karakteristik para peserta didik, mengembangkan kurikulum dan silabus, perancangan pembelajaran, memanfaatkan teknologi, serta memberdayakan teknologi dalam setiap proses pembelajaran yang akan dilakukan, pemanfaatan berbagai metode mengajar yang komunikatif, mengisyaratkan pentingnya pengembangan teknologi pendidikan dan proses pembelajaran harus berbasis teknologi, dan membina jasmani dan ruhani peserta didik dengan segenap potensi yang ada pada keduanya secara berimbang,

${ }^{39}$ Lihat Yûsuf al-Qardhâwi, al-'Tbâdah fí al-Islâm (Kairo: Maktabah al-Wahbah, 1985), h. 255.

${ }^{40}$ Shihab, Tafsir al-Mishbah, Vol. IX, h. 102. 
sehingga dapat dilahirkan manusia yang seutuhnya. (2) konsep Tafsir al-Mishbah tentang kompetensi kepribadian, terdiri atas akhlak mulia yang harus dimiliki seorang guru yang profesional, seperti bertakwa kepada Allah SWT., adil, ikhlas, santun, lemah lembut, rendah hati, tidak kasar dan tidak berhati keras, memberi maaf, kemudian melaksanakan segala sesuatu dengan proses musyawarah, dan apabila musyawarah telah disepakati maka bertawakal kepada Allah SWT., melaksanakan segala aktivitas keprofesiannya sebagai wujud kecintaannya kepada sang Khalik, mempunyai kewibawaan yang baik yang dapat mengendalikan peserta didiknya ke arah yang baik, tidak mudah terpengaruh dan terprovokasi dengan apa yang dilihat oleh mata dan apa yang didengar oleh telinga serta apa yang dirasakan oleh hati, memiliki usia yang dewasa, pengetahuan yang mendalam serta kedewasaan berpikir (kematangan berpikir), mengedepankan kejujuran ketika mengajar di dalam kelas, menjadi teladan bagi peserta didik dan masyarakat melalui ucapannya (lisan), melalui karya ilmiahnya (tulisan) dan melalui berbagai aktivitas kehidupannya serta melalui akhlaknya, secara berkelanjutan terus mengevaluasi dirinya atas apa yang ia lakukan, atas apa yang ia katakan, atas apa yang ia tuliskan, atas apa yang ia rencanakan dan atas apa yang telah dipersembahkannya untuk peserta didik, agama dan bangsa, dan mengembangkan dirinya secara berkelanjutan. (3) Konsep Tafsir al-Mishbah tentang kompetensi profesional, terdiri atas beberapa hal berikut: mampu mengungkap konsep dan contoh aktual serta mampu memaparkan urgensi konsep dan contoh tersebut dalam kehidupan nyata peserta didik, dan metode pembelajaran yang ditawarkan guru adalah metode pembelajaran yang tidak hanya bisa dilihat oleh mata dan didengar oleh telinga, namun metode yang ditawarkan adalah metode yang dapat menyentuh hati dan jiwa peserta didik. (4) Konsep Tafsir al-Mishbah tentang kompetensi sosial, terdiri atas: kemampuan guru dalam menggunakan bahasa, logika berpikir, penggunaan kata-kata yang syarat makna serta cara penyampaian yang tepat oleh pendidik akan berdampak positif kepada perkembangan peserta didik, menggunakan teknologi komunikasi dan informasi secara fungsional, menggunakan komunikasi yang baik, memilih perbendaharaan kata yang santun, penggunaan bahasa yang baik serta penggunaan suara yang baik (sesuai dengan kondisi di mana ia berada), mengedepankan baik sangka, berbicara dengan lemah lembut serta berbicara berdasarkan pengetahuan bukan ketidaktahuan di samping melakukannya berdasarkan pertimbangan logis dan nilai-nilai yang ditetapkan Allah SWT., dan mengedepankan semangat kebersamaan di atas perbedaan, mengedepankan saling melengkapi antara satu dengan yang lainnya, serta mengedapankan perbaikan untuk bersama bukan untuk saling mencela.

Kedua, mekanisme pembentukan profesionalitas guru dalam Tafsir al-Mishbah terdiri atas: memahami standar tuntutan profesi yang ada, mencapai kualifikasi dan kompetensi yang dipersyaratkan, membangun kesejawatan yang baik dan luas termasuk lewat organisasi profesi, mengembangkan etos kerja atau budaya kerja yang mengutamakan pelayanan, dan mengadopsi inovasi atau mengembangkan kreativitas dalam pemanfaatan teknologi komunikasi dan informasi mutakhir. 
Berdasarkan temuan di atas, dapat diajukan saran-saran sebagai berikut. Pertama, bagi pemerintah pusat dan daerah, perlu adanya perhatian khusus untuk terus meningkatkan profesionalitas guru dalam berbagai bentuk kebijakan, program maupun anggaran yang mencukupi. Kedua, bagi instansi terkait seperti Kemendiknas dan Kemenag, perlu adanya upaya pembinaan yang berkelanjutan, program peningkatan profesionalitas guru dalam profesi dan jabatan, keberpihakan terhadap kebijakan kesejahteraan guru serta perlu adanya jalinan kerjasama dengan organisasi profesi guru dalam meningkatkan profesionalitas guru. Ketiga, bagi organisasi profesi guru, perlu adanya program-program kegiatan yang dapat meningkatkan profesionalitas guru serta membangun kerjasama dengan berbagai pihak dalam rangka peningkatan profesionalitas guru. Keempat, bagi kepala madrasah/ sekolah, perlu adanya pembinaan dan evaluasi berkelanjutan terhadap tenaga pendidik dan kependidikan demi terciptanya profesionalitas kerja. Kelima, bagi guru, perlu adanya niat yang baik, motivasi yang kuat, keperdulian, keseriusan, kesabaran dan semangat yang tinggi dalam meningkatkan kualitas diri dalam rangka menciptakan pendidik yang profesional.

\section{Pustaka Acuan}

Al-Qardhâwi, Yûsuf. al-'Ibâdah fí al-Islâm. Kairo: Maktabah Wahbah. 1985.

Al-Marâghi, Ahmad Mushthafâ. Tafsîr al-Marâghi. Beirut: Dâr al-Fikr, t.t.

Nata, Abuddin. Tafsir Ayat-Ayat Pendidikan: Tafsîr al-Âyât al-Tarbawiy. Jakarta: RajaGrafindo Persada, 2002.

Nizar, Samsul. Filsafat Pendidikan Islam: Pendekatan Historis, Teoritis dan Praktis. Jakarta: Ciputat Press, 2002.

Nurdin, Syafruddin dan M. Basyiruddin Usman. Guru Profesional dan Implementasi Kurikulum. Jakarta: Ciputat Press, 2003.

Siahaan, Amiruddin dan Tohar Bayoangin. Manajemen Pengembangan Profesi. Bandung: Citapustaka Media, 2014.

Shihab, M. Quraish. Tafsir al-Mishbah: Pesan, Kesan dan Keserasian al-Qur'ân, Vol. I-XV. Jakarta: Lentera Hati, 2011.

Shihab, M. Quraish. Tafsir al-Qur'ân al-Karîm: Tafsir atas Surat-Surat Pendek Berdasarkan Urutan Turunnya Wahyu. Bandung: Pustaka Hidayah, 1997.

Yustiyawan, Rachman Halim dan Desi Nurhikmahyanti. "Pengaruh Motivasi dan Kompetensi Profesional Guru yang Bersertifikasi terhadap Kinerja Guru di SMP Negeri 1," dalam Jurnal Inspirasi Manajemen Pendidikan, Vol. 3. No. 3, 2014.

Undang-Undang No. 14 Tahun 2005 tentang Guru dan Dosen.

“99.387 Guru Belum Sarjana-Pemerintah Diminta Biayai Pendidikan Guru," dalam http:// koran-sindo.com, diakses 12 November 2014. 